\title{
A STRATEGIC INTEGRATED HEALTHCARE FACILITY MANAGEMENT MODEL
}

\author{
Sarel LAVY $1 \bowtie$ and Igal M. SHOHET ${ }^{2}$ \\ 1 Department of Construction Science, College of Architecture, Texas A\&M University, \\ 422A Langford, 3137 TAMU, College Station, Texas 77843-3137, USA \\ E-mail: slavy@archmail.tamu.edu \\ 2 Division of Construction Management, Department of Structural Engineering, Ben-Gurion \\ University, P.O.B. 653, Beer Sheva 84105, Israel \\ E-mail: igals@bgu.ac.il
}

Received 4 September 2006; accepted 22 June 2007

\begin{abstract}
The requirement to reduce expenditure on "non-core" activities, along with building's owners' expectations for improved performance, are the main dilemmas with which a facility manager deals on a regular basis. The primary objective of this research was to identify the effect of defined parameters, such as the actual age of a building and its level of occupancy, on the performance of facilities and their systems. This study contributed to the development of a model capable of integrating these parameters into a Facility Management (FM) tactical and strategic decision-making process, referred to as the Integrated Healthcare Facility Management Model (IHFMM). The model's guidelines may be outlined for the methodological design and operation of facilities from a life cycle perspective. The paper presents the architecture of the developed model, and four of the 15 procedures that comprise the heart of this model.
\end{abstract}

KEYWORDS: Healthcare; Facility management; Occupancy; Performance; Service life planning

\section{INTRODUCTION}

Increased competition in the business sector drives companies to reduce expenditures on "non-core" activities. At the same time, buildings' owners and users have increased their expectations and requirements of facilities. These competing demands are the main dilemmas with which a facility manager deals on a regular basis.

Five processes have led the area of facility management (FM) to become one of the most important for business success: (1) increased construction costs, particularly in the public sector; (2) greater recognition of the effects of space upon productivity; (3) increased performance requirements; (4) contemporary bureaucratic and statutory restrictions that decelerate start up of new construction projects; and (5) performance of high-rise buildings that are highly dependent on maintenance (Shohet, 2005). Consequently, the traditional "maintenance manager" has become a "facility manager," and is a key individual in an organization's continuity and success. The facility manager is responsible for making critical strategic and operational facilities-planning decisions that affect the organization's business performance. This is particularly true in healthcare facilities, considered one of the most compli-

International Journal of Strategic Property Management

ISSN 1648-715X print / ISSN 1648-9179 online (C) 2007 Vilnius Gediminas Technical University

http://www.ijspm.vgtu.lt 
cated and difficult types of facilities to manage, maintain, and operate. The facility manager must make daily decisions in numerous areas, such as maintenance policy, level of performance, sources of labor, acceptable level of risk, etc.

This paper presents the principles and the architecture of the Integrated Healthcare Facility Management Model (IHFMM). The IHFMM model is composed of 15 procedures that have been developed within the framework of this research. The paper, however, describes the outlines according to which four key procedures (out of the 15 composing the model) were developed.

\section{LITERATURE BACKGROUND}

Facility management has traditionally been regarded in the old-fashioned sense of cleaning, repairs and maintenance (Atkin and Brooks, 2000; Regterschot, 1990) while FM responsibilities were defined as "buying, selling, developing and adapting stock to meet wants of owners regarding finance, space, location, quality and so on" (O'Sullivan and Powell, 1990). Nowadays, facility management is known as "an integrated approach to maintaining, improving and adapting the buildings of an organization in order to create an environment that strongly supports the primary objectives of that organization," as well as to achieve a balanced, high performing organization (Barrett, 2000). Then (1999) recognizes that "the FM role is to meet the business challenges that confront the organization it is supporting, for reaching the optimum balance between people, physical assets and technology."

Healthcare facility management topics are discussed widely in the literature. Natural population growth, aging of the population, and the consumer revolution have all increased the demand for health services in public hospitals (Hosking and Jarvis, 2003). Consequently, the total number of in- and out-patient admissions has increased. In order to deal effectively with the increased number of in-patient admissions, and as a result of their limited resources, hospitals have reduced the average length of stay (AHA, 2004; Federal Statistical Office Germany, 2003). These trends have led to an increasing investigation of the structure of healthcare systems and facility management decision-making in this industry. Melin and Granath (2004) conducted a study in Sweden on the effect of "Horizontal Integrated Care" (HIC deals with ways that care is delivered to patients) on facility management; Payne and Rees (1999) discuss the importance of an integrated facility management system in hospitals; Procter and Brown (1997) present a case study in which an information support system was implemented in a hospital in the UK; and Waring and Wainwright (2002) discuss the significance of implementation of Information and Communication Technologies (ICT) in the National Health Service (NHS) facility management system.

Examination of FM in the healthcare sector exposes an underinvestment in the allocation of resources (AHA, 2004; British Ministry of Finance, 2003). This lack of attention might adversely affect the non-core activities of healthcare providers, and particularly facility management aspects, such as maintenance activities and operations.

Drivers of healthcare facility management are discussed extensively in the literature. Gallagher (1998), for instance, defines the following six issues as encouraging successful implementation of healthcare FM: strategic planning, customer care, market testing, benchmarking, environmental management, and staff development. Amaratunga et al., (2002) define the following attributes as key processes for successful implementation of FM: service requirements management, service planning, service performance monitoring, supplier and contractor management, health and safety processes, risk management, and serv- 
ice coordination. Shohet and Lavy (2004b) identify the following five core domains (the "pentagon") within the area of healthcare facility management: maintenance management, performance management, risk management, supply services management, and development. Information and Communications Technologies (ICT) is treated as an integrator among all five domains. These healthcare facility management core domains are closely interconnected, and a modification of any one affects the others. The model this paper presents is composed of the five core domains of healthcare FM defined above as the pentagon of healthcare FM.

The problem of healthcare facility management is characterized by the existence of different types of data, including both quantitative data (e.g. maintenance resources, physical performance, and energy consumption), and data that require a means of quantification for implementation in FM (e.g. type of facility, and maintenance policy). Moreover, data for most healthcare facilities studied in extant research was partially missing or incomplete. Furthermore, the type of solution and the reasoning mechanism for FM policy setting and decisionmaking involves integrating statistical knowledge of the phenomenon with previous experience and heuristics of other cases. As a result, the Structural Case-Based Reasoning approach was found to be the most appropriate technique for solving healthcare FM decision-making problems.

\section{OBJECTIVES}

The complexity of decision-making in facility management requires a hierarchical evaluation process, where perceptive understanding of the effects of multiple factors is essential. During the life cycle of an asset, many decisions must be made so as to provide its owners and users with optimal conditions. The primary objective of this research was to quantify the effect of defined parameters, such as the actual age of a building, level of occupancy, level of outsourcing, and maintenance expenditure, on the performance of facilities and their systems. The performance of the built environment is defined in this research as the fitness of the functional state of the facility to its intended use. The performance of the facility is measured using the Building Performance Indicator (BPI), developed in an earlier stage of this research. Based on this, research efforts focused on developing an artificial intelligence model capable of integrating the above parameters into a Facility Management decisionmaking process for FM policy setting and strategic planning. This main research objective has been subdivided into the following goals: (1) identifying core parameters for management of system-intensive healthcare facilities throughout the service life of the building; (2) determining performance criteria for assessing the core parameters; and (3) establishing a multi-disciplinary (managerial, economic, technological) hierarchical knowledge base for an integrated FM model that supports the prediction of performance and risk of various buildings and systems in the facility.

The research method included the following phases:

1. Field survey (data gathering): carried out with a structured questionnaire, designed to identify core parameters for management of healthcare facilities;

2. Statistical analyses of the data collected in the field survey: revealed the main parameters affecting the field of healthcare facility management;

3. Conceptual development of the decisionmaking model (IHFMM): the five core themes of healthcare FM were identified;

4. Computing of the decision-making model: described in detail in the following paragraphs; and

5. Feasibility evaluation of the model: implementing the model in two case studies in Israeli public acute-care hospi- 
tals. Sensitivity analyses were carried out to examine the sensitivity of the results to variations in the model's parameters.

\section{THE INTEGRATED HEALTHCARE FACILITY MANAGEMENT MODEL (IHFMM)}

\section{Architecture of the Model}

This section delineates the architecture and rationale behind the Integrated Healthcare Facility Management Model (IHFMM). A comprehensive model should deal with all aspects of healthcare FM, as mentioned in the background literature (Shohet and Lavy, 2004b) and shown in Figure 1. Some components have already been developed in other studies, such as the development of the facility. Shen and
Lo (1999), and Shen and Spedding (1998), for instance, offer a model that prioritizes maintenance tasks by weighing six criteria, three of which are physical condition, importance of usage, and cost implications. This can be used as a decision-support tool while planning maintenance projects. Likewise, in the framework of this research, only the first two modules of the IHFMM (maintenance management and performance and risk management) were thoroughly investigated as a decision-support tool. In addition, the relationships between the two modules' parameters were studied.

The model proposed in this research provides insight into the assessment of parameters that affect maintenance management, and performance and risk management in healthcare facilities. The proposed model is divided into three main interfaces: Input In-

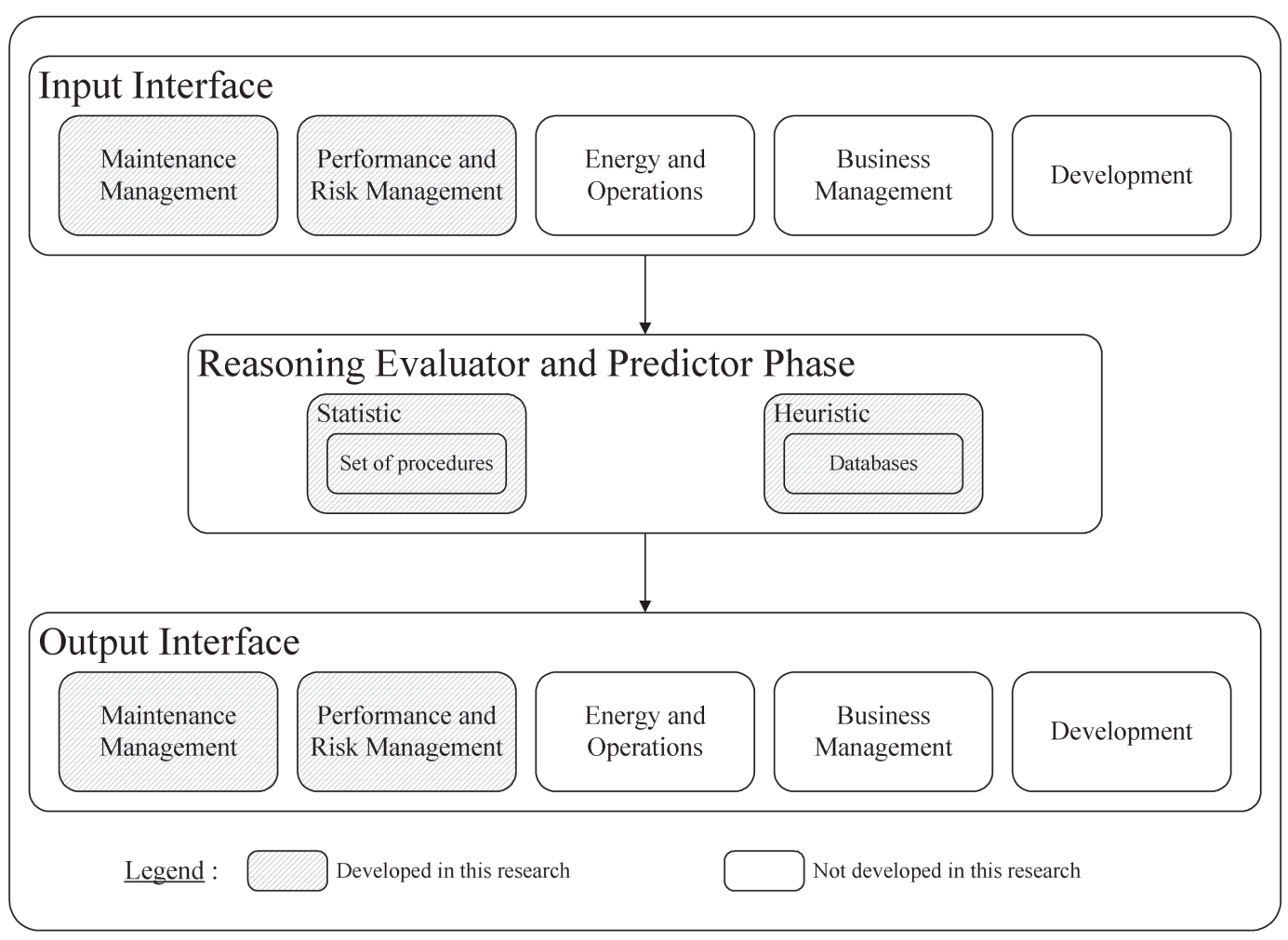

Figure 1. The architecture of the Integrated Healthcare Facility management Model 
terface, Reasoning Evaluator and Predictor, and Output Interface, which are subdivided into five phases (A to E), as described in the following paragraphs.

\section{The Input Interface}

The Input Interface is subdivided into two phases: (A) Facility phase; and (B) Buildings, systems and components phase. In these two phases, a variety of input parameters relevant to the facility in question are required of the user. This interface requires general data about the facility (e.g., type of facility [principal/peripheral], availability of labor, designation of areas with the facility [medical wards, utilities, outpatient clinics, laboratories, offices]), as well as specific data for each particular building and system in the facility (e.g., actual age and required service life of buildings, actual and required performance for components and systems, and actual maintenance policies). This interface uses a database of building components for each sampled building, for which the reinstatement value (cost of reconstruction) per sq-m of floor area, Designed Life Cycle, replacement cost per sq-m, and annual maintenance costs are given. The Input Interface also employs several databases, such as the pattern of deterioration for each of the building's main components.

The first phase of the Input Interface (Phase A) deals with general data from the facility; while the second (Phase B), deals with particular data from each building surveyed. These two phases are further subdivided into the following four layers: Phase A includes Layer 1 - Facility: general data about the facility (type of facility, geographical location, number of patient beds, and availability of labor). Phase B is subdivided into three layers. These layers represent the input of particular data for each building, where each layer refers to a different aspect of the facility. The first layer in this phase, Layer 2 - Building, deals with aspects related to the design pa- rameters of the surveyed buildings (such as floor area per building, actual age of buildings, and required service life of buildings). Layer 3 - System - deals with maintenance and required performance of each particular building system. Each building was broken into 10 building systems, for which the following information is needed: maintenance policy per building system, required level of performance score, and the level of risk attributed to the system's physical performance score. The last layer in this phase, Layer 4 - Component, addresses the particular components in the different building systems. This layer requires information such as reinstatement value of each component, its annual maintenance and replacement costs, and its actual physical performance score. Some of the data is collected simultaneously at two layers; for example, annual maintenance expenditure is analyzed at both the facility level (for measurement of overall effectiveness of maintenance activities at this level) and at the component level (identifying effectiveness of maintenance for a particular component). The Input Interface is designed according to a deductive reasoning approach, i.e. from the general facility level to the specific components level. It begins by acquiring general facility data, then buildings and systems, and finally it acquires particular and detailed data about the specific components.

\section{The Reasoning Evaluator and Predictor Interface}

The Reasoning Evaluator and Predictor Interface is both the mind and the heart of the developed model, since it includes the calculating, analyzing, and deducing stages of the facility's Key Performance Indicators. This interface includes a single phase - Key Performance Indicators (Phase C) - in which the different procedures of the IHFMM are implemented. This phase is composed of 15 procedures, based on previous studies and on the 
statistical analyses of the field survey carried out in the preliminary stages of the current research (presented and discussed in Shohet and Lavy, 2004a). The Reasoning Evaluator and Predictor Interface measures and predicts KPI's of maintenance, performance, and risk for the facility, the buildings, the systems, and their components. Thus, a set of outcomes and recommendations is deduced, as described in the following paragraphs.

The scheme of the Reasoning Evaluator and Predictor Interface is presented in Figure 2. As seen in Figure 2, this interface is sub-divided into three hierarchical layers, i.e. the procedures are implemented and computed from Facility Parameters (Layer 5), through Actual Indicators of the facility FM (Layer 6), to Prediction Indicators of facility performance (Layer 7).

The Facility Parameters layer (Layer 5) im- plements seven procedures that calculate and determine the following parameters in the surveyed facility: (1) facility coefficient calculates an economic coefficient that assesses the amount of resources allocated on an annual basis for implementing annual maintenance activities (as detailed in the following paragraphs); (2) facility area calculates the total surveyed floor area; (3) Total Annual Maintenance Expenditure (TAME) indicates the sum of actual annual maintenance expenditure spent for the whole facility; (4) required performance indicator shows the required level of performance (as set by the facility manager) for the different buildings and systems on-campus, as measured on a 100-point scale (Shohet et al., 2003); (5) building systems' weights in the performance indicator calculates the economic weights (based on Life Cycle Costs analysis) with which the systems in each sur-

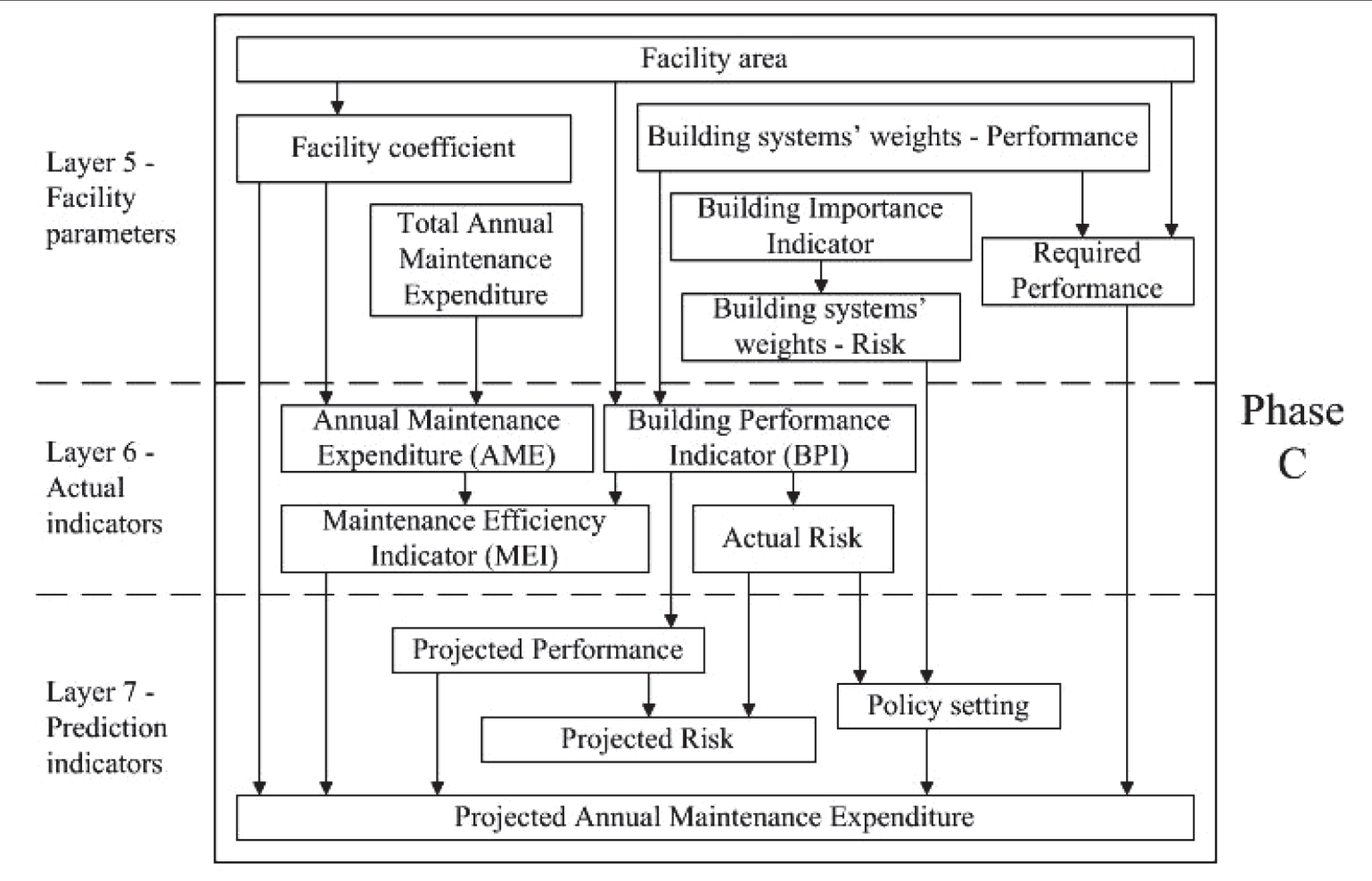

Figure 2. Scheme of the Reasoning Evaluator and Predictor Interface 
veyed building are weighted in the different performance indicators; (6) Building Importance Indicator (BII) indicates the priority setting according to which the surveyed buildings are prioritized for maintenance, as defined by the facility manager; and (7) building systems' weights in the risk indicator shows the potential risk involved in the maintenance of different building systems, defined by a combination of parameters, such as the area of the building and the vitality of the system (for example, medical gases and fire protection systems ought to be in a much higher risk category than the interior finishes and the exterior envelope systems).

As seen in Figure 2, some of Layer 5's outputs are used by Layer 6 (Actual Indicators layer), including the following four procedures.

(1) Maintenance Efficiency Indicator (MEI) indicates the efficiency with which maintenance activities are implemented (as detailed in the following paragraphs).

(2) Annual Maintenance Expenditure is the annual resources allocated for maintenance activities per building.

(3) Building Performance Indicator (BPI) indicates the actual performance of the surveyed buildings on a 100-point scale, weighted according to their systems' and components' shares in the building's Life Cycle Costs (as weighted in procedure no. 5 in Layer 5). The BPI score is measured by using previously defined performance scales (Shohet, 2003). An example of the scales used for measuring performance is given in Appendix A, where a given scale for exterior cladding system performance rating is presented. A similar scaling system was used to evaluate the level of performance of 51 components in a building.

(4) Actual risk indicates the actual levels of risk with regard to each of the systems in the surveyed buildings, de- fined by a default set of rules that can be modified by the user and measured on a 5-point scale (Very Low, Low, Moderate, High, and Very High).

The main outcomes of this interface are shown in Layer 7 - The Prediction Indicators layer, which constitutes four procedures for computing the following projections for FM planning of a facility: (1) Projected Annual Maintenance Expenditure (PAME) per built sq$\mathrm{m}$ of floor area in a facility - this procedure computes the annual maintenance expenditure required to perform a given maintenance policy under a given condition of the facility; (2) projected performance indicator for different components, systems, buildings, and for the entire facility - projects the future physical condition of the facility, buildings, and systems for a given actual condition and a given maintenance policy; (3) projected level of risk involved in maintaining the buildings - projects the level of risk of systems and buildings for a given actual physical condition and risk, and a given maintenance policy; and (4) policy setting, to compare the surveyed facility with other similar facilities, based on "best practice cases."

\section{The Output Interface}

The Output Interface provides the user with the analyses and results of the facility in question on a variety of topics: economic, performance, risk, maintenance policy setting, and sources of labor. This interface implements inductive reasoning, i.e., the policy setting and output parameters are deduced from the component to system layer; the latter layers are then incorporated into the analysis of the building and facility. In this interface, the user begins with the results of the analyses conducted in the Reasoning Evaluator and Predictor interface. The Output Interface is subdivided into two phases: the first phase of the Output Interface (Phase $\mathrm{D}$ ) deals with particular data for the facility, including economic (e.g., pro- 
jected Annual Maintenance Expenditure), performance (e.g., projected level of performance), and risk (e.g., projected level of risk) aspects, which are divided into the following four layers: Components Evaluation, Systems Analysis, Building Analysis, and Facility Analysis (Layers 8 to 11). The second phase (Phase E) compares the facility's main Key Performance Indicators with other facilities, and includes Policy Setting for maintenance and sources of labor for each of the systems and buildings in the facility (Layer 12).

Two principles outline the design of the proposed IHFMM, as follows:

1. The architecture of the database is object-oriented, enabling adaptability to diverse healthcare facilities and buildings. This attribute makes the model flexible and capable of receiving information about different types of healthcare buildings, according to particular configurations; and

2. The model links the six core issues of strategic healthcare FM. Although the developed modules deal simultaneously with aspects related to maintenance, performance and risk of healthcare facilities, future development will expand to include energy and operations, business management, and development aspects.

The following paragraphs outline the rationale behind selecting four main procedures out of the 15 specified in this research for in-depth analysis, namely the facility coefficient, the projected performance, the Maintenance Efficiency Indicator, and actual risk, drawn from the Reasoning Evaluator and Predictor Interface (Figure 2). The facility coefficient is key for determining projected maintenance and actual maintenance efficiency; and projected performance is associated with the projection of future performance and risk in the facility.
Being able to correctly predict maintenance efficiency, future performance and actual risk forms the basis of healthcare FM's contribution to overall organizational efficiency.

\section{Facility Coefficient}

The facility coefficient determines projected maintenance and assesses actual maintenance efficiency. This procedure assumes that annual maintenance expenditure is affected by four independent variables: (1) category of environment in which the facility is located (marine vs. in-land); (2) level of occupancy (number of patient-beds per 1,000 sq-m built, with standard occupancy being 10 patient-beds per 1,000 sq-m.); (3) actual age of the buildings in the facility (years since completion of construction); and (4) designation of built areas in the building, such as hospitalization wards, offices, laboratories, clinics, and utility areas (the more complex the building the higher the maintenance demands) (Lavy and Shohet, 2007a). It should also be stressed that this coefficient refers merely to the projected expenditure for maintenance. ${ }^{1}$

The facility coefficient procedure is an economic coefficient used in computing the Annual Maintenance Expenditure, by adjusting a coefficient for each of the surveyed buildings in the facility, and for the entire facility. This economic coefficient expresses the maintenance resources required for implementing a preventive maintenance policy based on the facility's level of occupancy, type of environment, age of buildings, and the components included in the buildings.

As mentioned above, the assumption made in the development of this procedure is that the facility coefficient is affected by the four main variables in the following manner: (1) age of the building dictates the replacement of building components; (2) category of environ-

\footnotetext{
1 The facility coefficient has no relevance to revenue escalation as a result of other conditions, such as increased number of patients accommodated in a given area, or the level of utilization of certain areas in the facility.
} 
ment (marine or in-land) affects the deterioration of exterior building components, as seen in Table 1; (3) average occupancy level of the facility (defined as the number of patient beds per $1,000 \mathrm{sq}-\mathrm{m}$, where 10 patient-beds per $1,000 \mathrm{sq}-\mathrm{m}$ are characterized as standard $100 \%$ occupancy) affects the deterioration of interior building components, as seen in Table 1; and (4) the configuration of each building (e.g., hospitalization wards require different building systems and components than warehouses). The model assumes that the type of environment and the level of occupancy variables are statistically independent. Occupancy level affects the life cycle of a component, or its annual maintenance costs, or both-particularly in the case of indoor components that are exposed to intensive or moderate service conditions (Table 1). Marine environment affects the life cycle of a component and its annual maintenance costs, particularly in the case of outdoor components that are exposed to severe environmental conditions (Building Performance Group Ltd., 1999; Construction Audit Ltd., 1999). In addition, each component is assumed to be replaced at the end of its life cycle, unless the residual service life of the building is less than half of the component's Designed Life Cycle. In that case, the component continues to serve the building until the end of the building's life cycle (Allweil, 1989).
The facility coefficient is an adjusting coefficient for the maintenance of the actual facility, compared to a standard hospitalization building at standard service conditions used as a reference case. The standard service conditions are defined to be in-land environment and standard level of occupancy $(100 \%)$. The facility coefficient represents an annual snapshot indication - an increase or decrease in the required maintenance resources; it is thus calculated on a yearly basis. A facility coefficient of 1.25 , for example, represents an increase of $25 \%$ in the annual maintenance resources compared with a standard hospital building, under standard service conditions (occupancy and environment). It does not mean that in general, the cost of maintenance is $25 \%$ higher for one type of environment or occupancy level as measured against the standard; however, does indicate that additional resources are required for the particular year for which the coefficient is calculated. The facility coefficient for any building changes during the service life of the building, based on its unique configuration of systems and components. The facility coefficient provides an analytical means for service life planning of facilities; this coefficient can be used to allocate resources to the maintenance of the facility from a long-term service life planning perspective.

The facility coefficient is used in the pro-

Table 1. Effect of facility parameters on the facility coefficient

\begin{tabular}{|c|c|c|}
\hline Occupancy & In-land Environment & Marine Environment \\
\hline $\begin{array}{l}\text { Low } \\
(80 \% \text { or lower })\end{array}$ & $\begin{array}{l}\text { Relevant interior components - } \\
\text { Longer life cycles, and lower annual } \\
\text { maintenance costs. }\end{array}$ & $\begin{array}{l}\text { Relevant exterior components - Shorter life cycles, } \\
\text { and higher annual maintenance costs. } \\
\text { Relevant interior components - Longer life cycles, } \\
\text { and lower annual maintenance costs. }\end{array}$ \\
\hline $\begin{array}{l}\text { Standard (bet- } \\
\text { ween } 80 \% \text { and } \\
133 \%)\end{array}$ & $\begin{array}{l}\text { Reference case (refers to } 100 \% \\
\text { occupancy). }\end{array}$ & $\begin{array}{l}\text { Relevant exterior components - Shorter life cycles, } \\
\text { and higher annual maintenance costs. }\end{array}$ \\
\hline $\begin{array}{l}\text { High }(133 \% \text { or } \\
\text { higher) }\end{array}$ & $\begin{array}{l}\text { Relevant interior components - } \\
\text { Shorter life cycles, and higher annual } \\
\text { maintenance costs. }\end{array}$ & $\begin{array}{l}\text { Relevant exterior components - Shorter life cycles, } \\
\text { and higher annual maintenance costs. } \\
\text { Relevant interior components - Shorter life cycles, } \\
\text { and higher annual maintenance costs. }\end{array}$ \\
\hline
\end{tabular}


jection of annual maintenance resources required by healthcare facilities. The coefficient enables the delineation of resources required for replacement and maintenance activities; based on this outline, an annual maintenance plan can be created. This coefficient is also used in the Maintenance Efficiency Indicator to evaluate the actual efficiency with which maintenance activities are implemented. Most assumptions used for developing the facility coefficient procedure are parametric, and as a result, they can be modified and adapted for other types of buildings and situations. The facility coefficient procedure uses the Life-Cycle Costs analysis, and applies it to different environmental and occupancy conditions over a designed life cycle of 75 years (Figure 3 and Appendix B). The figure was produced from simulations of the building's maintenance under six combinations of environmental and occupancy service conditions. Figure 3 depicts that the cumulative effect of marine environment and high occupancy adds up to an increase of $19 \%$ in maintenance life cycle costs. Conversely, light service conditions, i.e. low occupancy, lead to a $10 \%$ decrease in the cumulative facility coefficient. These findings are explained by statutory regulatory requirements for preventive maintenance of most of the electro-mechanical systems within the building, even under partial occupancy conditions. Comparison of the cumulative coefficient for standard occupancy and marine vs. in-land environment reveals that the effect of marine environments accumulates to only $2.1 \%$. The cumulative effect of high occupancy is found to be as high as $14 \%$.

\section{Projected Performance Procedure}

Projected performance is associated with the projection of future performance and risk in the facility. This procedure projects the performance score for each component and system, used to compute the projected performance indicator for each surveyed building, as well as for the entire facility. This procedure provides a projection of the physical performance score of buildings' components and systems, measured on a 100-point scale, based on their actual physical performance.

The deterioration pattern of each component in the structural system is assumed to be non-linear (Bentur et al., 1997), as found in a field survey conducted during an earlier phase of this research (Equation 1):

$$
\begin{aligned}
& y=124.29 * \exp \left(-0.08139 * t^{0.5289}\right) \\
& 8 \leq t \leq 63
\end{aligned}
$$

This equation represents the deterioration in performance, where $y$ is the projected performance score for year $t$. The correlation coefficient of this equation was found to be $R^{2}=0.65$, representing structural components in an in-land environment, between 8 and 63 years of age. During this period of time, performance decreases exponentially from 97.33 points to 60 points. A similar analysis was conducted for buildings in a marine environment.

However, the deterioration pattern of each component in all systems other than the structural system was assumed to be linear (Equation 2). The linear pattern of deterioration assumes standard service conditions that yield time-dependent linear deterioration of building components, based on previous research findings that linear patterns of deterioration are appropriate and valid for interior components and exterior claddings (Shohet and Paciuk, 2004; Moubray, 1997).

$$
P P_{i, j, k}=A P_{i, j, k}-\frac{40}{d l c_{j, k}},
$$

where: $P P_{i, j, k}=$ Projected performance score for component $k$ of system $\mathrm{j}$ in building $i ; A P_{i, j, k}=$ Actual performance score for component $k$ of system $j$ in building $i$; and $d l_{j, k}=$ Designed life cycle for component $k$ of system $j$. 


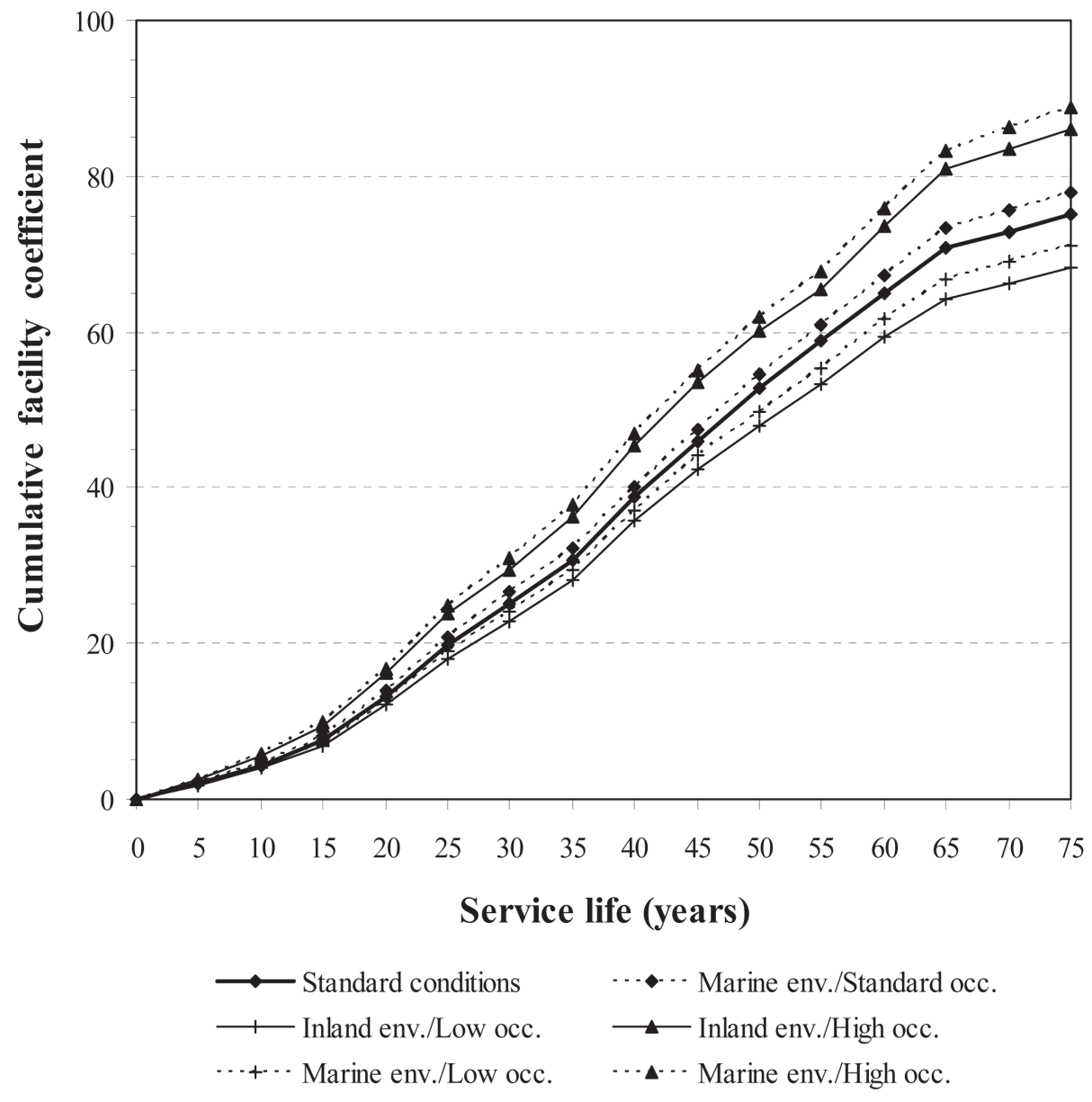

Figure 3. Cumulative facility coefficient along building's service life for various conditions

Although this was not proven for all building components, and since this research does not investigate the exact pattern of deterioration for all components, the linearity assumption was made in order to simplify the calculation process. However, the equations used in this research are parametric, so future studies could replace these equations with others, if they are found to be more accurate and precise.

The weight of each system in the building's performance indicator is calculated as the ratio between the system's Life Cycle Costs
(LCC) and the building's LCC. Since this ratio weighs the systems based on their LCC relative to the total LCC of the building, it represents a physical performance score weighted on the basis of the LCC criterion. This criterion sets a service life planning means for the allocation of maintenance resources.

The prediction of a building's performance indicator projects future functioning level based on actual monitoring of its performance and on other assumptions, as detailed above. In this research, patterns of performance projection were developed for all 51 main hospi- 
tal building components. Based on this, future performance can be projected for each system in the building, for the building as a whole, and for the entire facility that is composed of several buildings (Lavy and Shohet, 2007b).

The process of performance projection includes two patterns of deterioration: non-linear and linear deterioration. Although the concept of different patterns of deterioration is well documented in the literature, this research advances one step further: it proposes the use of these patterns of deterioration to not only project the performance of a single element or system in a building, but to project it for the entire building and even of the entire facility, using Life Cycle Costs as the weighting principle for the various building systems. Moreover, it allows decision-makers to break each building down into its separate systems, and to analyze it in great detail, down to its components.

\section{Maintenance Efficiency Indicator Procedure}

This procedure computes the Maintenance Efficiency Indicator (MEI), which indicates the actual efficiency with which maintenance activities are implemented. The MEI range of values for healthcare facilities is defined as: (1) lower than 0.37 , representing a high level of efficiency; (2) between 0.37 and 0.52 , representing a standard level of efficiency, with 0.45 being the middle of this range; and (3) higher than 0.52 , representing a low level of efficiency. These values are based on a desired performance level of 90 points, 25 years as an average age of Israeli healthcare facilities, and Annual Maintenance Expenditure that assumes implementation of a preventive maintenance policy (Shohet et al., 2003). In order to calculate the Maintenance Efficiency Indicator, this procedure uses the following two indicators: (1) the Normalized Annual Maintenance Expenditure (NAME) which is the adjusted Annual Maintenance Expenditure - this value expresses the maintenance expenditure, weighing the effects of the building's age and level of occupancy (Shohet et al., 2003); and (2) the actual Building Performance Indicator (BPI) for the entire facility, measured on a 100-point scale. The MEI calculation is shown in Equation 3. The NAME itself is composed of two parameters: (1) the Annual Maintenance Expenditure, which is the annual amount of resources per sq-m spent on maintenance activities in the facility; and (2) the facility coefficient, representing the maintenance resources for implementing preventive maintenance policy. This calculation is shown in Equation 4.

$$
\begin{aligned}
& M E I=\frac{N A M E}{B P I}, \\
& N A M E=\frac{A M E}{F A C(y)},
\end{aligned}
$$

where: $M E I=$ Maintenance Efficiency Indicator; $N A M E=$ Normalized Annual Maintenance Expenditure ( $\$$ US per sq-m); BPI = Building Performance Indicator for the facility; $A M E=$ Annual Maintenance Expenditure (\$US per sq$\mathrm{m}$ ); and $F A C(y)=$ Facility coefficient for year $y$.

Figure 4 delineates the Maintenance Efficiency Indicator on a two dimensional graph where the vertical axis represents the BPI scores of the buildings, while the horizontal axis represents the NAME. The diagonal dashed line represents the normative standard level of MEI (0.45) in hospital facilities in Israel, and the other two lines provide the upper and lower boundaries of this range as derived from the standard deviation of the sample population. This diagram provides a strategic tool for long-range facility management in healthcare. On the vertical axis, the diagram allows setting of performance benchmarks and short as well as long-term objectives. The horizontal axis provides a clear means for economic evaluation of the annual expenditure on main- 
tenance. The normative lines set the criteria for efficient maintenance (MEI $= \pm 0.37$ ), standard efficiency $(\mathrm{MEI}= \pm 0.45$ ), and poor efficiency $(\mathrm{MEI}>0.52)$.

\section{Actual Risk Procedure}

This procedure aims to categorize the actual level of risk for each system in each building. The risk scales were defined as ordinal scales with five categories of risk: Very Low, Low, Standard, High, and Dangerous. This procedure provides an indication for the level of risk associated with each of the 51 main components in a building (also discussed in the Building Performance Indicator (BPI) procedure). The assumption is that the following two parameters characterize a risk level: (1) actual Building Performance Indicator and (2) actual maintenance policy and design parameters. Table 2 presents the calculation method for the actual risk for one building component - the control panels, which are part of the elevator system. The values presented in this table are parametric, and were developed as an average of the responses received from a survey of five Israeli healthcare facility managers in public acute-care hospitals; therefore, these are the model's default values. However, since these are parametric figures, they may be changed and adapted according to the specific requirements of each type of building and for each user's needs.

Based on this table, the actual risk of any specific component may be deduced according to the higher option, i.e., if the BPI shows an actual risk category of Low, but the maintenance policy fits the actual risk category of Standard, then the final actual risk of that component will be Standard (the higher value of Low and Standard). If the BPI is lower than 30 points, then the maintenance policy has no affect on the actual risk, which means that it remains Dangerous, regardless of the maintenance policy.

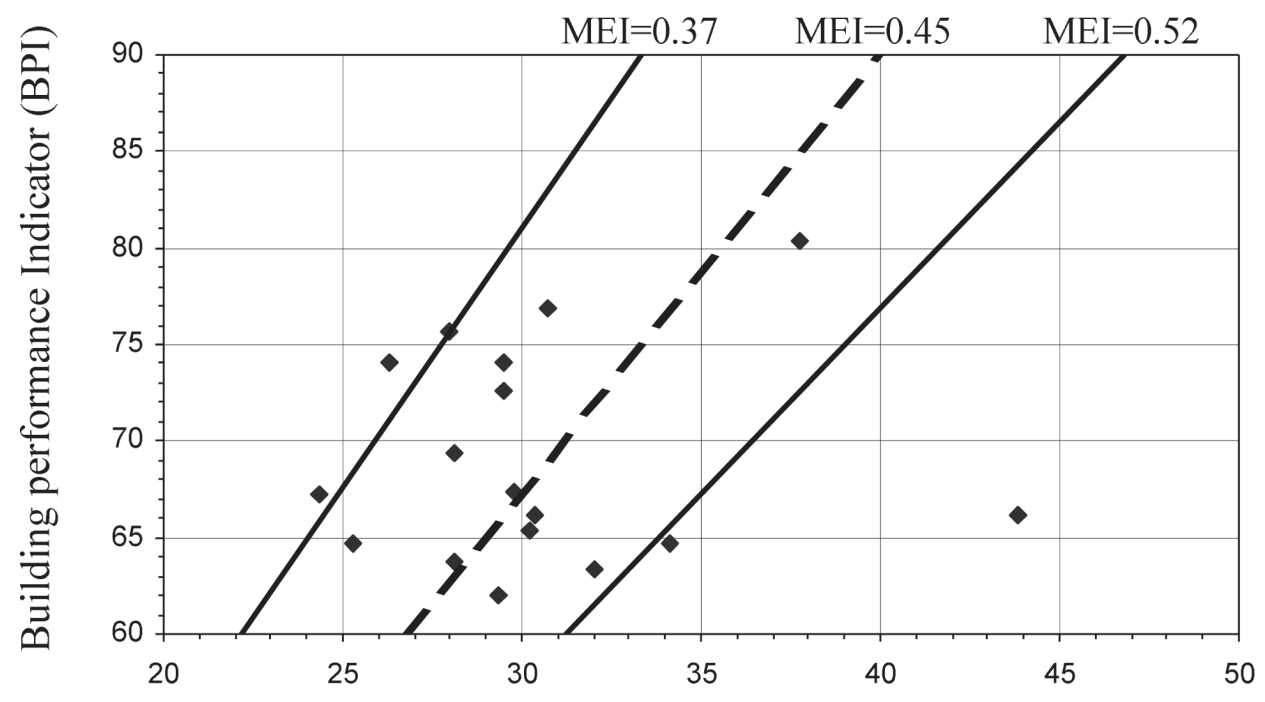

Normalized Annual Maintenance Expenditure (NAME) [\$US per sq.m.]

Figure 4. Normative range of MEI on a BPI vs. NAME-graph 
Table 2. Actual risk for control panels, elevator system

\begin{tabular}{lll}
\hline $\begin{array}{l}\text { Level of Risk } \\
\text { Category }\end{array}$ & $\begin{array}{l}\text { Building } \\
\text { Performance } \\
\text { Indicator }\end{array}$ & Maintenance Policy \\
\hline Very Low & $>90$ & $\begin{array}{l}\text { Inspection of elevators is implemented twice a year by an authorized } \\
\text { inspector, and in crowded buildings, detailed inspection (including control } \\
\text { system, command board, mechanical condition, etc.) of elevators is } \\
\text { implemented monthly, or more frequently. } \\
\text { Inspection of elevators is implemented twice a year by an authorized } \\
\text { inspector, and in crowded buildings, detailed inspection of elevators is } \\
\text { implemented quarterly, or more frequently. }\end{array}$ \\
Low & $70-90$ & $\begin{array}{l}\text { Inspection of elevators is implemented twice a year by an authorized } \\
\text { inspector, and in crowded buildings, detailed inspection is not } \\
\text { implemented. }\end{array}$ \\
Inspection of elevators is implemented less than twice a year by an \\
authorized inspector. \\
No inspection of elevators is implemented.
\end{tabular}

\section{CONCLUSIONS}

The research proposes deductive hierarchical reasoning for strategic healthcare facility management. The reasoning mechanism implements integrated analyses of Key Performance Indicators that shed light on organizational effectiveness and efficiency of healthcare FM, and on performance and maintenance policy setting.

When making a decision, a facility manager must consider many factors in FM decisionmaking. Yet, existing models supporting decision-making processes are quite limited, particularly at the strategic level of facilities management. This may be attributed to the fact that the integration between the different parameters of the facility has not yet been researched thoroughly, particularly with reference to the effects of these parameters on the facility's service life planning. As a result, this research focused on the identification of principal variables affecting the performance and maintenance of facilities throughout their service life. These parameters were drawn together into an analytical Integrated Healthcare Facility Management Model, which proposes simultaneous diagnosis and analysis of the complexities involved in this intricate area. Almost all facility managers and owners of public and private facilities face these complexities. Managing these complexities is, however, more critical in healthcare facilities that operate 24 hours a day, 7 days a week, provide emergency intensive and life-saving care and treatment services, and support critical infrastructure of healthcare, such as power supply for operating theaters, and medical gas in intensive care units.

The development of the IHFMM enhances the existing body of knowledge about the management of built facilities and provides generic parameters, as well as methods, for the complicated decision-making processes in healthcare facility management. It enables the facility management discipline to become more structured and quantitative by offering simultaneous hierarchical analysis of healthcare FM core parameters, as seen by the structure of the model. The IHFMM may provide a means for coping with complexities, such as insufficient data, that the facility management discipline often faces. In addition, the developed IHFMM may provide new means and concepts for measuring the effectiveness and efficiency of performance and operations of facilities. 
The proposed IHFMM could assist healthcare facilities managers in their FM-related decision-making process, as it creates the basis for strategic decision-making in facility management. The facility coefficient procedure, for example, shows significant evidence that the maintenance expenditure in a building significantly depends on a combination of factors that have not been taken into consideration in previous research, such as the age of the building, its level of occupancy, and even the type of environment in which the building is located. The projected performance procedure can be used as an indicator for the projection of the physical condition of a building and its various systems and components, by using linear and non-linear patterns of deterioration for each specific component. Based on these two parameters, strategic decision-making, such as determining the best investment in terms of resource allocation and even broader aspects of facility management which were not discussed in this paper, such as space planning and workplace design, can be undertaken. The third procedure this paper deals with is the Maintenance Efficiency Indicator that expresses the efficiency with which resources are utilized. Using this indicator provides strategic decision-makers with a powerful tool in terms of identifying required changes in order to improve efficiency and productivity in implementing maintenance work. The fourth procedure is the actual risk procedure that combines the physical performance and maintenance policy into a 5-point scale representing the risk associated with a building and its various systems and components. Using each of these procedures by itself can add an important component to strategic facility management; however, using the IHFMM as an inclusive model for healthcare facility management has the capacity to make considerable changes in this process.

Nevertheless, the model is not yet complete; the current modules must be further studied, and the modules that this research did not address, such as energy consumption and operation costs, should be studied and combined into a comprehensive Integrated Healthcare Facility Management Model. This research may also be extended to include analyses of performance, risk, and patterns of deterioration vs. annual revenue and level of occupancy. Moreover, this study was conducted on Israeli hospital buildings. Implementing it in hospital buildings in other parts of the world will require adjustments and modifications of the different indicators to reflect local environmental conditions and construction. Furthermore, a similar, continuing study was conducted on office buildings (Shohet et al., 2006); its findings support these conclusions.

Based on this research, and using the developed procedures, guidelines for strategic facility management may be outlined for the methodological design and operation of facilities from a life cycle perspective. The development of the analytical quantitative model may significantly contribute to a better understanding of healthcare facility management, as well as contribute to measuring efficiency, and improving FM performance.

\section{REFERENCES}

Allweil, A. (1989) Maintenance Expenditure in Different Types of Buildings, Third research report of Life Cycle Costs of Buildings, National Building Research Institute, Haifa, Israel (in Hebrew).

Amaratunga, D., Haigh, R., Sarshar, M. and Baldry, D. (2002) Assessment of facilities management process capability: A NHS facilities case study. International Journal of Health Care Quality Assurance, 15(6), p. 277-288.

American Hospital Association (AHA) (2004) TrendWatch Chartbook 2004: Trends affecting hospitals and health systems - September 2004, <http://www.hospitalconnect. com/ ahapolicy forum/trendwatch/chartbook2004. html>, (June 2004). 
Atkin, B. and Brooks, A. (2000) Total Facilities Management, Blackwell Science, Oxford, U.K.

Barrett, P. (2000) Achieving strategic facilities management through strong relationship. Facilities, 18(10/11/12), p. 421-426.

Bentur, A., Diamond, S. and Berke, N. S. (1997) Steel Corrosion in Concrete: Fundamentals, and Civil Engineering Practice, E\&FN Spon, London, U.K.

British Ministry of Finance (2003) Budget 2003: Report - Chapter 6: Delivering high quality public services, <http://www.hm-treasury. gov.uk/budget/bud_bud03/budget_report/ bud_bud03_repchap6.cfm>, (February 2005).

Building Performance Group Ltd. (1999) BPG Building Fabric Component Life Manual, E\&FN Spon, London, U.K.

Construction Audit Ltd. (1999) HAPM (Housing Association Property Mutual) Component Life Manual, E\&FN Spon, London, U.K.

Federal Statistical Office Germany (2003) Facilities, beds and patient turnout: Hospitals, 1991-2003, <http://www.destatis.de/basis/e/gesu/ gesutab29.htm>, (June 2004).

Gallagher, M. (1998) Evolution of facilities management in the health care sector, Construction Papers, No. 86, 1-8, The Chartered Institute of Building, Editor: P. Harlow.

Hosking, J. E. and Jarvis, R. J. (2003) Developing a replacement facility strategy: Lessons from the healthcare sector. Journal of Facilities $M a$ nagement, 2(3), p. 214-228.

Lavy, S. and Shohet, I. M. (2007a) On the effect of service life conditions on the maintenance of healthcare facilities. Accepted for publication in Construction Management and Economics.

Lavy, S. and Shohet, I. M. (2007b) Computer-aided healthcare facility management. Accepted for publication in Journal of Computing in Civil Engineering.

Melin, A. and Granath, J. A. (2004) Patient focused healthcare: an important concept for provision and management of space and services to the healthcare sector. Facilities, 22(11/12), p. 284289.

Moubray, J. (1997) Reliability-Centred Maintenance, $2^{\text {nd }}$ ed., Butterworth-Heinemann, Oxford, MA, U.S.A.

O’Sullivan, P. E. and Powell, G. C. (1990) Facilities management: growth and consequences, Proceedings of the International Symposium on
Property Maintenance Management and Modernization, CIB International Council for Building Research Studies and Documentation Working Commission 70, Singapore, Vol. 1, pp. 156-161.

Payne, T. and Rees, D. (1999) NHS facilities management: a prescription for change. Facilities, 17(7/8), p. 217-221.

Procter, S. and Brown, A. D. (1997) Computer-integrated operations: The introduction of a hospital information support system. International Journal of Operations \& Production Management, 17(8), p. 746-756.

Regterschot, J. (1990) Facility management in changing organizations, Proceedings of the International Symposium on Property Maintenance Management and Modernization, CIB International Council for Building Research Studies and Documentation Working Commission 70, Singapore, Vol. 1, pp. 146-155.

Shen, Q. and Lo, K. K. (1999) Priority setting in maintenance management, The Hong-Kong Polytechnic University, Kowloon, Hong-Kong.

Shen, Q. and Spedding, A. (1998) Priority setting in planned maintenance - practical issues in using the multi-attribute approach. Building Research and Information, 26(3), p. 169-180.

Shohet, I. M. (2003) Building evaluation methodology for setting maintenance priorities in hospital buildings. Construction Management and Economics, 21(7), p. 681-692.

Shohet, I. M. (2005) Key performance indicators for strategic healthcare facilities maintenance. Journal of Construction Engineering and $M a$ nagement-ASCE. In Press.

Shohet, I. M., Lavy-Leibovich, S. and Baron, D. (2003) Integrated maintenance monitoring of hospital buildings. Construction Management and Economics, 21(2), p. 219-228.

Shohet, I. M. and Lavy, S. (2004a) Development of an integrated healthcare facilities management model. Facilities, 22(5/6), p. 129-140.

Shohet, I. M. and Lavy, S. (2004b) Healthcare facilities management: State of the art review. Facilities, 22(7/8), p. 210-220.

Shohet, I. M. and Paciuk, M. (2004) Service life prediction of exterior cladding components under standard conditions. Construction Management and Economics, 22(10), p. 1081-1090.

Shohet, I. M., Park, C. S. and Augenbroe, G. (2006) Key Performance Indicators for public office fa- 
cilities maintenance, Proceedings of the CIB W70 2006 Trondheim International Symposium, Changing User Demands on Buildings: Needs for Lifecycle Planning and Management, Norway, June 12-14, 2006. pp. 253-264.

Then, D. S. S. (1999) An integrated resource man- agement view of facilities management. Facilities, 17(12/13), p. 462-469.

Waring, T. and Wainwright, D. (2002) Enhancing clinical and management discourse in ICT implementation. Journal of Management in Medicine, 16(2/3), p. 133-149.

\section{SANTRAUKA}

\section{STRATEGINIS INTEGRUOTAS SVEIKATOS PRIEŽIŪROS PASTATU ŪKIO VALDYMO MODELIS}

\section{Sarel LAVY, Igal M. SHOHET}

Reikalavimas mažinti „neesminès“ veiklos išlaidas bei pastato savininkų lūkesčiai dèl geresnių rezultatų - su tokiomis pagrindinèmis dilemomis reguliariai susiduria pastatų ūkio valdymo vadybininkas. Sio tiriamojo darbo pagrindinis uždavinys yra nustatyti, koks yra apibrežtu parametrų, tokių kaip realus pastato amžius ir jo užimtumo lygis, poveikis pastatų ir jų sistemų rezultatyvumui. Šis tyrimas prisidejjo kuriant modelį, kuris leidžia šiuos parametrus integruoti i taktinių ir strateginių pastatų ūkio valdymo sprendimų priëmimo procesą ir yra vadinamas integruotu sveikatos priežiūros pastatų ūkio valdymo modeliu. Modelio rekomendacijas galima taikyti vykdant metodologinị pastatu projektavimą ir eksploatavimą iš gyvavimo ciklo perspektyvos. Šiame darbe pristatoma sukurto modelio architektūra ir keturios iš penkiolikos procedūrų, sudarančių šio modelio šerdị. 


\section{APPENDIX A}

Performance rating scale for the exterior cladding system

\begin{tabular}{|c|c|c|c|c|}
\hline 100 & 80 & 60 & 40 & 20 \\
\hline VERY GOOD & GOOD & MARGINAL & RUN-DOWN & DANGEROUS \\
\hline $\begin{array}{l}\text { There are no cracks } \\
\text { or other visible } \\
\text { damage to exterior } \\
\text { claddings. No } \\
\text { claddings are falling } \\
\text { down or peeling off. }\end{array}$ & $\begin{array}{l}\text { Only localized } \\
\text { hairlines cracks } \\
\text { discernible here and } \\
\text { there, or localized } \\
\text { mould grows around } \\
\text { the horizontal edges } \\
\text { of the claddings. }\end{array}$ & $\begin{array}{l}\text { There are visible } \\
\text { cracks in less than } \\
5 \% \text { of the cladding } \\
\text { surface or falling } \\
\text { down of claddings is } \\
\text { observed in few } \\
\text { places. }\end{array}$ & $\begin{array}{l}\text { There are sizeable } \\
\text { cracks in more than } \\
5 \% \text { of the cladding } \\
\text { surface, or } \\
\text { substantial peeling } \\
\text { off or falling down } \\
\text { of claddings. }\end{array}$ & $\begin{array}{l}\text { Considerable part of } \\
\text { exterior cladding has } \\
\text { peeled off or fallen } \\
\text { down, and mould } \\
\text { grows on substantial } \\
\text { part of the } \\
\text { remaining cladding. }\end{array}$ \\
\hline
\end{tabular}

\section{APPENDIX B}

Facility coefficient, in different environmental and occupancy conditions for a hospital building with designed life cycle of 75 years

\begin{tabular}{lllllll}
\hline Building's & \multicolumn{5}{l}{ In-land Environment } & \multicolumn{3}{l}{ Marine Environment } \\
\cline { 2 - 6 } Service Life & Low & Standard & High & Low & Standard & High \\
& Occupancy & Occupancy & Occupancy & Occupancy & Occupancy & Occupancy \\
\hline 5 & 0.3714 & 0.4205 & 0.5121 & 0.4010 & 0.4501 & 0.5417 \\
10 & 0.4451 & 0.5289 & 0.6552 & 0.4742 & 0.5580 & 0.6843 \\
15 & 0.8259 & 0.8550 & 1.0324 & 0.8505 & 0.8797 & 1.0570 \\
20 & 1.1439 & 1.2032 & 1.4877 & 1.2055 & 1.2649 & 1.5493 \\
25 & 1.0695 & 1.2037 & 1.3640 & 1.1569 & 1.2912 & 1.4515 \\
30 & 1.0297 & 1.0800 & 1.1085 & 1.0665 & 1.1168 & 1.1453 \\
35 & 1.2743 & 1.3506 & 1.5974 & 1.2596 & 1.3359 & 1.5827 \\
40 & 1.5174 & 1.5311 & 1.7815 & 1.5369 & 1.5507 & 1.8010 \\
45 & 1.1860 & 1.3955 & 1.5034 & 1.2507 & 1.4601 & 1.5681 \\
50 & 0.9466 & 1.2929 & 1.2122 & 0.9926 & 1.3389 & 1.2582 \\
55 & 1.1890 & 1.2274 & 1.2866 & 1.2219 & 1.2603 & 1.3195 \\
60 & 1.1630 & 1.2343 & 1.5936 & 1.2047 & 1.2760 & 1.6353 \\
65 & 0.7023 & 0.8383 & 1.0537 & 0.7421 & 0.8781 & 1.0935 \\
70 & 0.4121 & 0.4212 & 0.5100 & 0.4501 & 0.4591 & 0.5480 \\
75 & 0.3980 & 0.3923 & 0.4970 & 0.4343 & 0.4287 & 0.5334 \\
\hline
\end{tabular}

